\title{
Lectotypification of Chamaecyparis hodginsii of the Cupressaceae
}

\author{
Zhi Yang', Yong Yang', Keith Rushforth ${ }^{2}$ \\ I College of Biology and the Environment, Nanjing Forestry University, 159 Longpan Rd., Nanjing 210037, \\ China 2 The Shippen, Ashill, Cullompton, Devon, EN15 3NL, UK \\ Corresponding author: Yong Yang (yangyong@njfu.edu.cn)
}

Academiceditor:DennisStevenson|Received27September2021|Accepted28October2021|Published 18November 2021

Citation: Yang Z, Yang Y, Rushforth K (2021) Lectotypification of Chamaecyparis hodginsii of the Cupressaceae. PhytoKeys 185: 117-122. https://doi.org/10.3897/phytokeys.185.75796

\begin{abstract}
Recent phylogenetic studies have suggested that the monotypic Fokienia A.Henry \& H.H.Thomas is nested within Chamaecyparis Spach, which is in agreement with separate morphological studies. Here the authors confirm a previous taxonomic treatment that incorporated Fokienia hodginsii (Dunn) A.Henry \& H.H.Thomas into Chamaecyparis based on the monophyly requirement of taxonomy, i.e. Chamaecyparis hodginsii (Dunn) Rushforth. In addition, the type collection of the basionym Cupressus hodginsii Dunn was found to contain three sheets of specimens, one in $\mathrm{K}$ including a vegetative branch (K000088294) and a separate ovulate cone (K001090486), a second one in A (A00022477), and a third one in IBSC (IBSC0016081). All three specimens are marked with Hongkong Herbarium No. 3505, but only the two specimens in K and IBSC possess similar handwriting of "Cupressus hodginsii Dunn". The two specimens should be considered as syntypes according to the Shenzhen Code. The specimen in K is better preserved but it is a mixture according to the collection label: cones from Foochow (Fuzhou) and foliage from Yenping (Nanping). We lectotypified the name Cupressus hodginsii with K000088294 because the specimen is well preserved and has enough characters for identification. Moreover, an ovulate cone (K001090486) is on the same sheet.
\end{abstract}

\section{Keywords}

Chamaecyparis hodginsii, lectotypification, nomenclature, taxonomy 


\section{Introduction}

Dunn (1908) described a new conifer species from Fujian of China, Cupressus hodginsii Dunn. Henry and Thomas (1911) believed that this species is different from Cupressus L. in the cone scale having only two seeds with two very unequal lateral wings, and should be classified into a separate genus, establishing Fokienia A.Henry \& H.H.Thomas (generic name is after the provincial name Fujian where the type was collected) and transferred the species into this monotypic genus, i.e. F. hodginsii (Dunn) A.Henry \& H.H.Thomas. Subsequently this monotypic genus was widely accepted and well known in botanical literature. Both Flora Reipublicae Popularis Sinicae (vol. 7, Wang et al. 1978) and Flora of China (vol. 4, Fu et al. 1999) treated it as a monotypic genus.

Since 2000, molecular systematic studies have consistently suggested that Fokienia is close to Chamaecyparis (Gadek et al. 2000; Yang et al. 2012; Qu et al. 2017; Stull et al. 2021). Based on a morphological study, Rushforth (2007) thought that the morphological variation of the genus Fokienia overlaps or falls within the range of Chamaecyparis including ovule number per cone scale, seed wing symmetry, and time duration for cone ripening, and thus reduced the genus to synonymy with Chamaecyparis, and made the combination Chamaecyparis hodginsii (Dunn) Rushforth. This morphological taxonomy was supported by a few subsequent phylogenetic studies (Mao et al. 2010, 2012; Jagel and Dörken 2015). Mao et al. (2012) sampled all extant five species of Chamaecyparis and the only species of Fokienia, assembled a sequence data including chloroplast, mitochondrial, and nuclear ribosomal DNA, and reconstructed a robust phylogeny of Cupressaceae; they demonstrated that Fokienia is nested within Chamaecyparis, with Fokienia hodginsii as sister to a subclade of Chamaecyparis including C. obtusa and C. lawsoniana, which received high bootstrap supports. The taxonomic treatment of Rushforth is acceptable if the monophyly principle is applied, and Chamaecyparis hodginsii should be the correct scientific name of the species.

Chamaecyparis hodginsii is a flag species of conservation. Fu (1992) recorded Fokienia hodginsii (EChamaecyparis hodginsii) in his China Plant Red Data Book: Rare and Endangered Plants; Qin et al. (2017) listed this species as threatened (VU). Chamaecyparis hodginsii is widely but sporadically distributed in southern China, Laos, and Vietnam. It has become a vulnerable species for a number of reasons, e.g. habitat loss, over exploitation, many old trees died of diseases, and difficult population regeneration (Chen et al. 2018). The recently released List of National Key Protected Wild Plants of China (ver. 2021) follows the treatment of the List of National Key Protected Wild Plants of China (Batch 1, ver. 1999), and lists the protection status of Fokienia hodginsii (EChamaecyparis hodginsii) as Grade II of protection.

In the protologue of Cupressus hodginsii Dunn, Dunn (1908) indicated a single collection, i.e. Hongkong Herbarium No. 3505, which should be considered as the type though he did not designate the herbarium where he deposited the type 


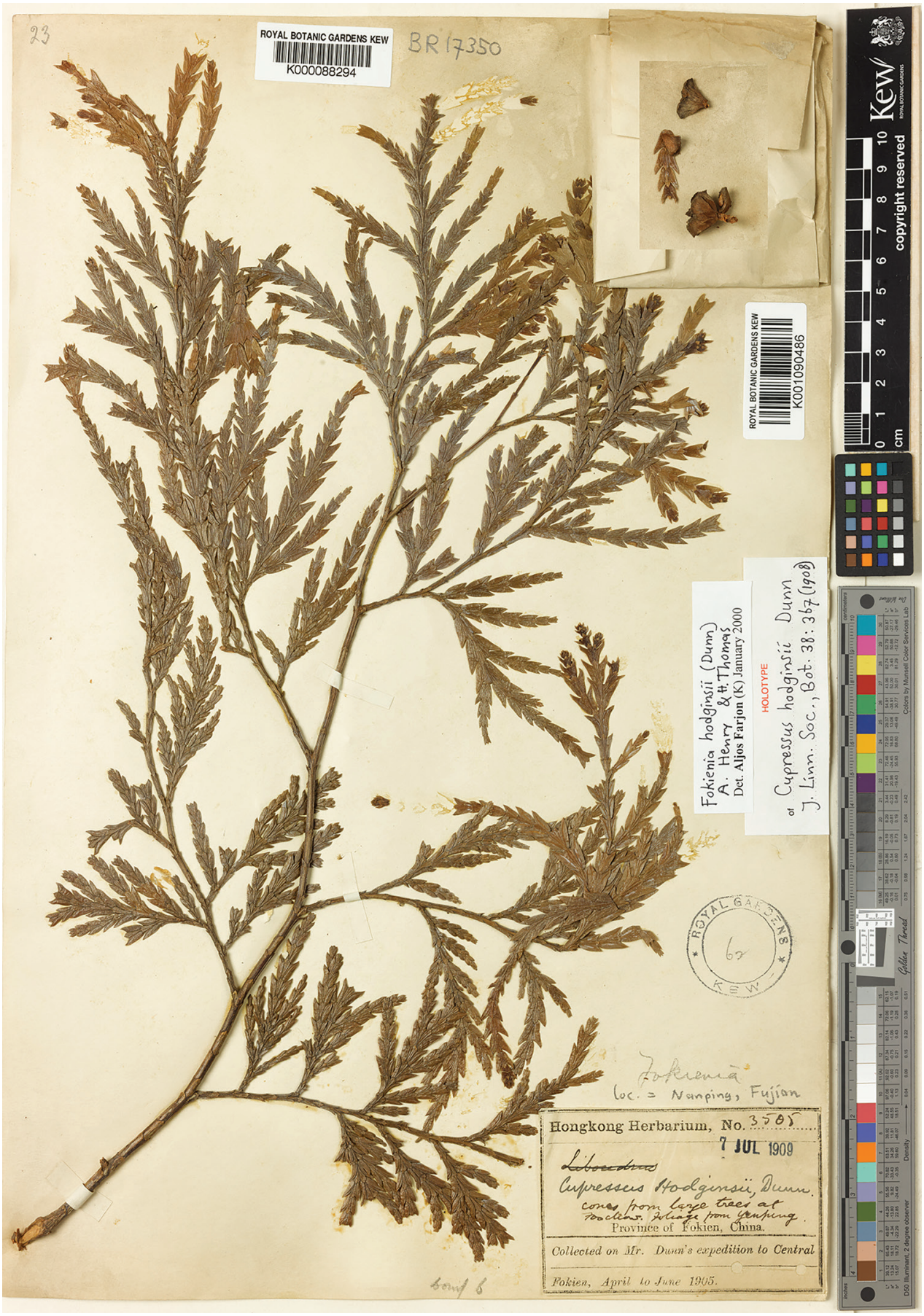

Figure I. Lectotype of Chamaecyparis hodginsii: Hongkong Herbarium No. 3505 (K000088294). 
specimen. We found three duplicates of the collection: one is deposited in the Kew Herbarium (Royal Botanical Garden, Kew) (Fig. 1) and includes a vegetative branch (K000088294) and a separate ovulate cone (K001090486); the label says "cones from large trees at Foochow, foliage from Yenping, Province of Fokien, China"; a second is in the Herbarium of South China Botanical Garden, Chinese Academy of Sciences (IBSC0016081), and a third is in Harvard University Herbaria (A00022477). Farjon (2010) considered the specimen in $\mathrm{K}$ is the holotype, which is obviously a mistake. The two duplicates in $\mathrm{K}$ and IBSC should be considered as syntypes under Art. 9.6 and 40.2 Note 1 of the Shenzhen Code (Turland et al. 2018), both were studied by Dunn because the identification label is marked with his handwriting while the sheet in A should be considered as an isosyntype because it lacks any handwriting label. A lectotype should be designated under Art. 9.11 and 9.12. The specimen in Kew is better preserved, and should be considered as the lectotype. However, that specimen is a mixture according to the collection note that the vegetative branch was collected from "Yenping (Nanping)" and the ovulate cone was from "large trees at Foochow (Fuzhou)". Here we designate the vegetative branch (K000088294) as the lectotype. This lectotype specimen clearly displays a few morphological characters of the species, i.e. dimorphic leaves 4-10 mm long, decussate, facial pairs closely appressed, lateral pairs boat-shaped and having two white depressed stomatal bands abaxially.

\section{Typification}

Chamaecyparis hodginsii (Dunn) Rushforth, J. Biol. (Vietnam) 29(3): 38 (2007) Fig. 1

ECupressus hodginsii Dunn, J. Linn. Soc., Bot. 38: 367 (1908); Fokienia hodginsii (Dunn) A.Henry \& H.H.Thomas, Gard. Chron. ser. 3, 49: 67 (1911).

Type. China. Fujian (福建, as “Fokien"): Nanping (南平, as “Yenping” in the protologue), April to June 1905, A.E.N. Hodgins, Hong Kong Herb. 3505 (lectotype: K000088294, designated here; isolectotypes: IBSC0016081, A00022477).

Distribution. China: Chongqing, Fujian, Guangdong, Guangxi, Guizhou, Hunan, Jiangxi, Sichuan, Yunnan, Zhejiang; Laos; VIetnam.

\section{Acknowledgements}

Images of the type collection of Chamaecyparis hodginsii were obtained from the Chinese Virtual Herbarium (CVH, http://www.cvh.ac.cn/), and Kew Herbarium (http:// apps.kew.org/herbcat/goto-HomePage.do). This work was supported by the National Natural Science Foundation of China [No. 31970205 \& 31770211], and a Metasequoia funding from the Nanjing Forestry University to Y.Yang. 


\section{References}

Chen F, Mu J, Huang L, Cui XY, Jin Y, Zhang L (2018) Features and succession analysis of Fokienia hodginsii communities in Sanchahe of Xishui National Nature Reserve, Guizhou Province. South China Forestry Science 46: 8-12.

Dunn ST (1908) A botanical expedition to central Fokien. Journal of the Linnean Society. Botany 38: 350-373. https://doi.org/10.1111/j.1095-8339.1908.tb00858.x

Farjon A (2010) A Handbook of the World's Conifers. Brill, Leiden-Boston. https://doi. org/10.1163/9789047430629

Fu LK (1992) China Plant Red Data Book: Rare and Endangered Plants (Vol. 1). Science Press, Beijing.

Fu LK, Yu YF, Farjon A (1999) Pinaceae. In: Wu CY, Raven PR (Eds) Flora of China (Vol. 4). Science Press, Beijing \& Missouri Botanical Garden, St. Louis, 62-77.

Gadek PA, Alpers DL, Heslewood MM, Quinn CJ (2000) Relationships within Cupressaceae sensu lato: A combined morphological and molecular approach. American Journal of Botany $87(7):$ 1044-1057. https://doi.org/10.2307/2657004

Henry A, Thomas HH (1911) A new genus of conifer. The Gardeners Chronicle: a Weekly Illustrated Journal of Horticulture and Allied Subjects, ser. 3 49: 66-68.

Jagel A, Dörken V (2015) Morphology and morphogenesis of the seed cones of the Cupressaceae - part II: Cupressoideae. Bulletin of the Cupressus Conservation Project 4(2): 51-78.

Mao KS, Hao G, Liu JQ, Adams RP, Milne RI (2010) Diversification and biogeography of Juniperus (Cupressaceae): Variable diversification rates and multiple intercontinental dispersals. The New Phytologist 188(1): 254-272. https://doi.org/10.1111/j.14698137.2010.03351.x

Mao KS, Milne RI, Zhang LB, Peng YL, Liu JQ, Thomas P, Mill RR, Renner SS (2012) Distribution of living Cupressaceae reflects the breakup of Pangea. Proceedings of the National Academy of Sciences of the United States of America 109: 7793-7798. https://doi. org/10.1073/pnas.1114319109

Qin HN, Yang Y, Dong SY, He Q, Jia Y, Zhao LN, Yu SX, Liu HY, Liu B, Yan YH, Xiang JY, Xia NH, Peng H, Li ZY, Zhang ZX, He XJ, Yin LK, Lin YL, Liu QR, Hou YT, Liu Y, Liu QX, Cao W, Li JQ, Chen SL, Jin XH, Gao TG, Chen WL, Ma HY, Geng YY, Jin XF, Chang CY, Jiang H, Cai L, Zang CX, Wu JY, Ye JF, Lai YJ, Liu B, Lin QW, Xue NX (2017) Threatened species list of China's higher plants. Biodiversity Science 25: 696-744. https:// doi.org/10.17520/biods.2017144

Qu XJ, Wu CS, Chaw SM, Yi TS (2017) Insights into the existence of isomeric plastomes in Cupressoideae (Cupressaceae). Genome Biology and Evolution 9(4): 1110-1119. https:// doi.org/10.1093/gbe/evx071

Rushforth K (2007) Notes on the Cupressaceae in Vietnam. Tap Chí Sinh Hoc [Journal of Biology. Hanoi, Vietnam] 29: 32-39. https://doi.org/10.15625/0866-7160/v29n3.5384

Stull GW, Qu XJ, Parins-Fukuchi C, Yang YY, Yang JB, Yang ZY, Hu Y, Ma H, Soltis PS, Soltis DE, Li DZ, Smith SA, Yi TS (2021) Gene duplications and genomic conflict underlie major pulses of phenotypic evolution in gymnosperms. Nature Plants 7(8): 1015-1025. https://doi.org/10.1038/s41477-021-00964-4 
Turland NJ, Wiersema JH, Barrie FR, Greuter W, Hawksworth DL, Herendeen PS, Knapp S, Kusber WH, Li DZ, Marhold K, May TW, McNeill J, Monro AM, Prado J, Price MJ, Smith GF [Eds] (2018) International Code of Nomenclature for algae, fungi, and plants (Shenzhen Code) adopted by the Nineteenth International Botanical Congress Shenzhen, China, July 2017. Regnum Vegetabile 159. Koeltz Botanical Books, Glashütten. https:// doi.org/10.12705/Code.2018

Wang WT, Cheng WC, Fu LK, Chu CD (1978) Cupressaceae. In: Cheng WC, Fu LK (Eds) Flora Reipublicae Popularis Sinicae (Vol. 7). Science Press, Beijing, 313-398.

Yang ZY, Ran JH, Wang XQ (2012) Three genome-based phylogeny of Cupressaceae s.l.: Further evidence for the evolution of gymnosperms and Southern Hemisphere biogeography. Molecular Phylogenetics and Evolution 64(3): 452-470. https://doi.org/10.1016/j. ympev.2012.05.004 